\title{
ISOLASI BAKTERI ASAM LAKTAT ASAL JUS NANAS SEBAGAI KANDIDAT PROBIOTIK
}

\author{
[Isolation of Lactic Acid Bacteria from Pineapple Juice as Probiotic Candidates]
}

\author{
Cynthia Rizka Riani ${ }^{1}$, Lilis Nuraida ${ }^{2,3)}$, dan Anja Meryandini ${ }^{4,5) *}$ \\ 1) Program Studi Mikrobiologi, Sekolah Pascasarjana, IPB University, Bogor \\ ${ }^{2)}$ Departemen Ilmu dan Teknologi Pangan, Fakultas Teknologi Pertanian, IPB University, Bogor \\ ${ }^{3)}$ Southeast Asian Food and Agricultural Science and Technology (SEAFAST) Center, IPB University, Bogor, \\ 4) Departemen Biologi, Fakultas Matematika dan IImu Pengetahuan Alam, IPB University, Bogor \\ ${ }^{5)}$ Pusat Penelitian Sumberdaya Hayati dan Bioteknologi (PPSHB), IPB University, Bogor
}

Diterima 12 Desember 2019 / Disetujui 20 Juli 2020

\begin{abstract}
Lactic acid bacteria ( $L A B)$ are the main group of probiotic bacteria that widely used in fruit juice fermentation products. Fruit juice contains antioxidants that can prevent free radicals. The objective of this study was to identify $L A B$ isolated from pineapple juice that possess probiotic properties and to analyze the antioxidant activity of pineapple juice after being fermented with the $L A B$. $L A B$ isolates from pineapple juice were evaluated for their probiotic properties (tolerance to acidic conditions and bile salts, antimicrobial activity against pathogenic bacteria, and sensitivity to antibiotics) and their adherence properties (autoaggregation, coaggregation, and hydrophobicity). The best isolates obtained are then inoculated into pineapple juice. From 5 types of pineapple juice, 5 isolates with $L A B$ characteristics were obtained, i.e NHC6, NHC7, NHC8, NHC9, and NPC1. Isolate NHC6 had a good tolerance to acidic conditions ( $\mathrm{pH} 2$ ) and $0,5 \%$ bile salt, had antimicrobial activity, was sensitive to ampicillin, showed the best adherance properties and was identified as Lactobacillus plantarum. L. plantarum NHC6 was then added to pineapple juice. Addition of L. plantarum NHC6 to pineapple juice reduced the ${ }^{\circ}$ Brix and $\mathrm{pH}$ values during incubation. After 24 hours of incubation, the antioxidant activity was 89,05\%, with LAB growth of 8,33 $\log \mathrm{CFU} / \mathrm{mL}$, thus 24 hours incubation was considered the best fermentation time for pineapple juice.
\end{abstract}

Keywords: antioxidants, fermentation, Lactobacillus plantarum, pineapple juice, probiotics

\begin{abstract}
ABSTRAK
Bakteri asam laktat (BAL) merupakan kelompok utama bakteri probiotik yang banyak digunakan pada produk fermentasi jus buah. Jus buah mengandung antioksidan yang berfungsi menangkal radikal bebas. Penelitian ini bertujuan untuk mengidentifikasi BAL hasil isolasi dari jus nanas yang memiliki sifat probiotik dan melihat aktivitas antioksidan jus nanas setelah difermentasi oleh BAL. Isolat BAL asal jus nanas diuji sifat probiotik (toleransi terhadap kondisi asam dan garam empedu, aktivitas antimikroba, serta kepekaan terhadap antibiotik) serta sifat penempelannya (autoagregasi, koagregasi, dan hidrofobisitas). Isolat terbaik yang diperoleh kemudian diinokulasi ke dalam jus nanas. Hasil isolasi dari 5 jenis jus nanas diperoleh 5 isolat dengan karakter BAL yaitu NHC6, NHC7, NHC8, NHC9, dan NPC1. Berdasarkan pengujian sifat probiotiknya, NHC6 memiliki toleransi yang baik pada kondisi asam dan $0,5 \%$ garam empedu, memiliki aktivitas antimikroba, sensitif terhadap ampisilin, menunjukkan sifat penempelan terbaik dan diidentifikasi sebagai Lactobacillus plantarum. L. plantarum NHC6 kemudian digunakan sebagai inokulum awal pada proses fermentasi jus nanas. Penambahan L. plantarum NHC6 pada jus nanas mampu menurunkan nilai ${ }^{\circ}$ Brix dan $\mathrm{pH}$ selama inkubasi. Setelah 24 jam inkubasi, diperoleh aktivitas antioksidan sebesar $89,05 \%$, dengan pertumbuhan BAL sebesar $8,33 \log \mathrm{CFU} / \mathrm{mL}$, sehingga pada jam ke24 inkubasi dianggap sebagai waktu inkubasi terbaik pada jus nanas.
\end{abstract}

Kata kunci: antioksidan, fermentasi, jus nanas, Lactobacillus plantarum, probiotik

*Penulis Korespondensi:

E-mail: ameryandini@apps.ipb.ac.id 


\section{PENDAHULUAN}

Makanan fungsional merupakan makanan yang mengandung satu atau lebih senyawa seperti probiotik, prebiotik, serat, dan antioksidan yang menyediakan fungsi penting bagi kesehatan. Makanan probiotik mewakili $60-70 \%$ dari makanan fungsional (Perricone et al., 2015). Kelompok bakteri probiotik yang sering ditemui pada produk makanan adalah bakteri asam laktat (BAL) seperti Lactobacillus dan Bifidobacterium (Sornplang dan Piyadeatsoontorn, 2016). BAL sebagai probiotik harus memiliki kriteria yang perlu dipertimbangkan sehingga dapat memberikan pengaruh positif bagi inangnya. Karakteristik probiotik yang harus dimiliki oleh BAL adalah tidak bersifat patogen, dapat menyesuaikan diri dengan lingkungan saluran pencernaan (tahan terhadap asam dan garam empedu), memiliki sifat antagonistik terhadap bakteri enterik, peka terhadap antibiotik, mampu menempel dan berkolonisasi pada usus manusia, serta dapat mempertahankan jumlah sel hidupnya pada saluran pencernaan manusia (Perricone et al., 2015; Panjaitan et al., 2018).

BAL dapat diperoleh dari berbagai macam sumber seperti buah dan produk-produk fermentasi. Beberapa spesies Lactobacillus diperoleh dari hasil isolasi pulp buah tropis, seperti $L$. plantarum, $L$. brevis, L. delbrueckii dengan beberapa sifat probiotik seperti tahan terhadap asam dan garam empedu, kemampuan menempel pada usus dan aktivitas antimikroba (Garcia et al., 2016). Phong et al. (2017) juga berhasil mengisolasi $L$. acidophilus $Y 1$ asal jus nanas dengan ketahanan terhadap asam. Selain itu, penambahan BAL dengan sifat probiotik pada buah juga diketahui mampu menjaga aktivitas antioksidan buah, termasuk pada jus nanas (Ferreira et al., 2016). Bakteri probiotik menyediakan sifat antioksidan dengan menghasilkan metabolit dengan aktivitas antioksidan seperti glutathion (GSH), butirat, dan folat (Budiari et al., 2019). Namun, belum ada kajian lebih lanjut mengenai hasil isolasi BAL dengan sifat probiotik lain yang harus dimiliki oleh BAL asal jus nanas sebagai probiotik dan aktivitas antioksidan pada jus nanas setelah difermentasi dengan BAL tersebut. Oleh karena itu, tujuan dari penelitian ini adalah untuk mendapatkan BAL hasil isolasi jus nanas yang memiliki karakteristik sebagai probiotik serta melihat aktivitas antioksidan jus nanas setelah penambahan BAL.

\section{BAHAN DAN METODE}

\section{Bahan}

Buah nanas diperoleh dari pasar lokal di kota Bogor (Honi), Jambi, Subang, dan Palembang. Bakteri patogen yang digunakan adalah Salmonella typhimurium ATCC 14028, Staphylococcus aureus ATCC 25923, dan Escherichia coli ATCC 25922 yang diperoleh dari Laboratorium Bioteknologi Hewan dan Biomedis (PPSHB) IPB University. BAL ditumbuhkan pada media mann rogosa sharpe (MRS) (Merck, Jerman) dan bakteri patogen ditumbuhkan pada media nutrient broth (NB) (Merck, Jerman).

\section{Persiapan jus nanas}

Nanas yang digunakan adalah nanas yang matang sempurna, tidak busuk, dan berwarna kuning oranye. Buah nanas dikupas dan dicuci bersih menggunakan air destilasi, lalu diekstraksi dengan menggunakan jus ekstraktor (WFA-4000, China).

\section{Isolasi dan identifikasi BAL asal jus nanas}

Isolasi dan identifikasi BAL asal jus nanas dilakukan berdasarkan metode Phong et al. (2017). Ekstrak jus nanas dimasukkan ke dalam gelas steril dan diinkubasi pada suhu $37^{\circ} \mathrm{C}$ hingga 48 jam. Hasil inkubasi ekstrak jus nanas sebanyak $1 \mathrm{~mL}$ diinokulasikan pada tabung yang berisi media MRS broth, lalu diinkubasi kembali pada suhu $37^{\circ} \mathrm{C}$ selama 24 jam. Bakteri yang tumbuh kemudian digores pada MRS padat. Identifikasi genus dilakukan dengan beberapa pengujian seperti pewarnaan Gram, uji katalase dan $\mathrm{CaCO}_{3} 0,3 \%(\mathrm{~b} / \mathrm{v})$.

\section{Uji toleransi BAL terhadap kondisi asam}

Pengujian toleransi BAL terhadap $\mathrm{pH}$ rendah berdasarkan metode Panjaitan et al. (2018) dengan modifikasi. MRS broth disesuaikan pHnya menjadi $\mathrm{pH} 2$ menggunakan $\mathrm{HCl} 37 \%$ (Merck, Jerman) dan diinokulasikan dengan 1\% (6,0 log CFU/mL) kultur BAL lalu selama 2 jam diinkubasi pada suhu $37^{\circ} \mathrm{C}$. Ketahanan terhadap $\mathrm{pH} 2$ dihitung berdasarkan selisih unit log jumlah koloni yang tumbuh pada waktu inokulasi awal $\left(T_{0}\right)$ dan 2 jam setelah inokulasi $\left(\mathrm{T}_{2}\right)$.

\section{Uji toleransi BAL terhadap garam empedu}

Toleransi BAL terhadap garam empedu berdasarkan Panjaitan et al. (2018). MRS broth yang mengandung $0,5 \%$ garam empedu (b/v) (Himedia) 
diinokulasikan dengan kultur BAL berumur 24 jam dan diinkubasi pada suhu $37^{\circ} \mathrm{C}$ selama 5 jam. Ketahanan terhadap $0,5 \%$ garam empedu $(\mathrm{b} / \mathrm{v})$ dihitung berdasarkan selisih unit log jumlah koloni yang tumbuh pada waktu inokulasi awal $\left(T_{0}\right)$ dan 5 jam setelah inokulasi $\left(T_{5}\right)$.

\section{Uji aktivitas antimikroba}

Aktivitas antimikroba dievaluasi berdasarkan Kos et al. (2003) dengan modifikasi. Kultur bakteri patogen uji dan BAL berumur 24 jam disentrifugasi (Tomy MRX-152, USA) pada kecepatan $7000 \mathrm{rpm}$ selama 10 menit untuk memperoleh supernatan bebas sel atau cell-free supernatant (CFS). CFS disterilkan dengan menggunakan membran filter (ukuran pori 0,22 $\mu \mathrm{m}$ ) (Millex-HV). CFS yang diperoleh dibagi menjadi 3 bagian, yaitu CFS tanpa perlakuan, CFS yang dinetralkan $(\mathrm{pH} 6,5)$ dengan penambahan $\mathrm{NaOH} 1 \mathrm{~N}$ (Merck, Jerman), dan CFS $\mathrm{pH}$ 6,5 yang dipekatkan. Pengujian aktivitas antimikroba CFS tanpa perlakuan dan CFS yang dinetralkan $(\mathrm{pH} 6,5)$ menggunakan metode difusi cakram, sedangkan CFS pH 6,5 yang dipekatkan menggunakan metode difusi agar (sumuran). Cawan petri berisi nutrient agar (NA) (Merck, Jerman) sebelumnya diinokulasikan dengan $200 \mu \mathrm{l}$ masingmasing bakteri patogen untuk setiap perlakuan supernatan. Kertas cakram steril (Oxoid, UK) diletakkan pada permukaan agar dan ditambahkan masing-masing sebanyak $20 \mu \mathrm{l}$ supernatan bebas sel (tanpa perlakuan dan pH 6,5). Pada CFS pH 6,5 yang dipekatkan, cawan petri berisi NA padat yang telah disiapkan dibuat sumuran menggunakan pipet steril. CFS pH 6,5 yang telah dipekatkan dimasukkan ke dalam tiap sumur dengan konsentrasi yang berbeda-beda $(25,50,75$, dan $100 \mu \mathrm{l})$ kemudian diinkubasi pada suhu $37^{\circ} \mathrm{C}$ selama 48 jam, lalu diukur zona bening yang terbentuk.

\section{Uji kepekaan terhadap antibiotik}

Kepekaan BAL terhadap antibiotik dilakukan dengan menggunakan metode Lee et al. (2014) dan Haque et al. (2014). Antibiotik yang digunakan adalah kloramfenikol $(50 \mu \mathrm{g})$ dan ampisilin $(10 \mu \mathrm{l})$. Larutan antibiotik disterilkan menggunakan membran filter (ukuran pori 0,22 $\mu \mathrm{m}$ ). Cawan petri yang berisi MRS padat sebelumnya telah diinokulasikan dengan $200 \mu \mathrm{l}\left(10^{7}-10^{8} \mathrm{CFU} / \mathrm{mL}\right)$ kultur BAL. Kertas cakram steril diletakkan di atas permukaan agar dan ditambahkan $20 \mu \mathrm{l}$ masing-masing larutan antibiotik, lalu diinkubasi pada suhu $37^{\circ} \mathrm{C}$ selama 24 jam. Diameter zona bening yang terbentuk diukur dan diinterpretasikan.

\section{Uji autoagregasi dan koagregasi}

Kemampuan autoagregasi dan koagregasi dilakukan berdasarkan metode Panjaitan et al. (2018). Kultur BAL berumur 18 jam disentrifugasi selama 20 menit pada kecepatan $3500 \mathrm{rpm}$. Pelet yang diperoleh dicuci 2 kali dengan PBS dan disuspensikan kedalam PBS baru hingga mencapai $10^{8}$ $\mathrm{CFU} / \mathrm{mL}$. Nilai autoagregasi ditentukan oleh pengukuran nilai absorbansi jam ke-0 dan absorbansi jam ke-5 setelah inkubasi pada suhu ruang. Pengukuran absorbansi dilakukan dengan mengambil $0,1 \mathrm{~mL}$ bagian atas suspensi dan dimasukkan kedalam 3,9 $\mathrm{mL}$ PBS yang kemudian diukur dengan spektrofotometer (Jenway 7205, UK) pada panjang gelombang $600 \mathrm{~nm}$. Persentase autoagregasi dihitung dengan rumus:

Autoagregasi $(\%)=1-\left(\frac{A_{t}}{A_{0}}\right) \times 100$

$A_{t}$ adalah nilai absorbansi jam ke-5 dan $A_{0}$ adalah nilai absorbansi jam ke-0 inkubasi.

Persiapan kultur BAL pada pengujian koagregasi dilakukan sama seperti autoagregasi, namun ditambahkan dengan sel bakteri patogen. Masingmasing suspensi BAL dan bakteri patogen diambil sebanyak $2 \mathrm{~mL}$ dan dicampurkan ke dalam tabung kosong. Tabung kontrol berisi $4 \mathrm{~mL}$ masing-masing suspensi sel bakteri patogen yang digunakan. Penentuan koagregasi dilakukan sama seperti autoagregasi. Persentase koagregasi dihitung dengan menggunakan rumus:

Koagregasi $(\%)=\frac{\left(\left(\frac{A_{x}+A_{y}}{2}\right)-A_{x}+A_{y}\right)}{\left(A_{x}+A_{y}\right)} \times 100 \ldots \ldots \ldots$.

$A_{x}$ adalah absorbansi suspensi isolat $B A L, A_{y}$ adalah absorbansi suspensi isolat patogen, dan $A_{x+y}$ adalah absorbansi campuran suspensi isolat BAL dan patogen.

\section{Penentuan sifat hidrofobisitas}

Penentuan sifat hidrofobisitas BAL dilakukan dengan menggunakan metode microbial adhesion to solvents (MATS) (Kos et al., 2003). Kultur BAL berumur 16-18 jam disentrifugasi selama 20 menit pada $3500 \mathrm{rpm}$. Pelet yang diperoleh dicuci 2 kali menggunakan bufer phosphate urea magnesium (PUM) dan disuspensikan ke dalam bufer PUM baru hingga mencapai jumlah $10^{8} \mathrm{CFU} / \mathrm{mL}$. Suspensi yang diperoleh kemudian diukur absorbansinya pada panjang 
gelombang $600 \mathrm{~nm}$ sebagai nilai absorbansi awal $\left(A_{0}\right)$. Suspensi sel pada bufer PUM diambil sebanyak $5 \mathrm{~mL}$ lalu dipindahkan ke dalam tabung kosong dan ditambahkan $1 \mathrm{~mL}$ hidrokarbon (xilena, etil asetat, dan kloroform) (Merck, Jerman) lalu divorteks (Gemmy VM-300, Taiwan) selama 1 menit. Tabung tersebut didiamkan selama 1 jam pada suhu $37^{\circ} \mathrm{C}$ agar terjadi pemisahan fase. Fase aqueous yang terbentuk dipindahkan dan diukur absorbansinya pada $600 \mathrm{~nm}$ sebagai nilai absorbansi akhir $\left(\mathrm{A}_{1}\right)$. Penurunan nilai absorbasi dinyatakan sebagai nilai hidrofobisitas dengan rumus:

Hidrofobisitas $(\%)=\left(\frac{\left(1-A_{0}\right)}{A_{1}}\right) \times 100$

\section{Identifikasi molekular BAL asal jus nanas}

Isolat BAL asal jus nanas kandidat probiotik diidentifikasi secara molekuler menggunakan gen 16S rRNA mengikuti prosedur Presto ${ }^{\text {TM }}$ Mini gDNA Bacteria Kit. Gen 16S rRNA diamplifikasi menggunakan mesin PCR T1-Thermarcycler. Primer yang digunakan adalah primer universal 63F (5'-CAG GCC TAA CAC ATG CAA GTC-3') dan 1387R (5'GGG CGG WGT GTA CAA GGC-3') (Marchesi et al., 1998). Kondisi PCR sebanyak 35 siklus terdiri atas pre-denaturasi pada $94^{\circ} \mathrm{C}$ selama 5 menit, denaturasi pada $94^{\circ} \mathrm{C}$ selama 30 detik, penempelan pada $55^{\circ} \mathrm{C}$ selama 45 detik, pemanjangan pada $72^{\circ} \mathrm{C}$ selama 1 menit 30 detik, setelah pemanjangan pada $72^{\circ} \mathrm{C}$ selama 10 menit, dan pendinginan pada suhu $4^{\circ} \mathrm{C}$. Produk PCR kemudian dikirim pada jasa sekuensing $1^{\text {st }}$ Base Malaysia untuk memperoleh runutan basa nukleotida. Hasil runutan basa nukleotida dianalisis menggunakan program nucleotide basic local alignment search tool (BLAST-n). Pembentukan pohon filogenetik menggunakan program Mega 6.0, metode neighbor joining ( $\mathrm{NJ}$ ) dengan bootstrap 1000x, dan model pohon Kimura-2-parameter.

\section{Fermentasi jus nanas dan uji kapasitas antioksi- dan}

Fermentasi jus nanas dilakukan menggunakan metode Phong et al. (2017) dengan modifikasi. Ekstrak jus nanas sebanyak $36 \mathrm{~mL}$ dipasteurisasi pada suhu $80^{\circ} \mathrm{C}$ selama 15 menit dan diinokulasikan sebanyak $4 \mathrm{~mL}$ kultur BAL $\left(10^{7} \mathrm{CFU} / \mathrm{mL}\right)$ berumur 24 jam dengan sifat probiotik terbaik. Sampel diinkubasi pada suhu $37^{\circ} \mathrm{C}$ selama 24 jam dan diambil sebanyak $2 \%(\mathrm{v} / \mathrm{v})$, setelah itu diinokulasikan pada ekstrak jus nanas terpasteurisasi yang baru dan diinkubasi 72 jam pada suhu $37^{\circ} \mathrm{C}$. Nilai $\mathrm{pH}$, ${ }^{\circ}$ Brix, densi- tas BAL, densitas khamir, dan aktivitas antioksidan dihitung setiap 0, 24, 48, dan 72 jam. Jus nanas yang terpasteurisasi tanpa diinokulasikan BAL diinkubasi dibawah kondisi yang sama sebagai kontrol non-fermentasi.

Hasil fermentasi jus nanas dan jus nanas nonfermentasi kemudian diuji aktivitas antioksidannya berdasarkan metode Li et al. (2018). Pengujian aktivitas antioksidan dilakukan dengan mencampurkan $1 \mathrm{~mL}$ sampel hasil fermentasi jus nanas dan kontrol pada $2 \mathrm{~mL}$ larutan metanolik DPPH (1,1-difenil-2pikrilhidrazil) (Merck, Jerman) 0,045 mg/mL. Campuran sampel divorteks dan diinkubasi dalam keadaan gelap selama 30 menit, lalu dihitung absorbansinya pada $517 \mathrm{~nm}$. Persentase aktivitas antioksidan dihitung menggunakan rumus:

Aktivitas Antioksidan $=\left(\frac{A_{0}-A_{s}}{A_{0}}\right) \times 100 \ldots \ldots \ldots \ldots \ldots$

$A_{0}$ adalah nilai absorbansi DPPH tanpa sampel dan $A_{s}$ adalah nilai absorbansi sampel.

\section{HASIL DAN PEMBAHASAN}

\section{Isolat BAL dari jus nanas}

Hasil isolasi kelima jus nanas diperoleh 28 isolat bakteri. Bakteri yang diperoleh memiliki morfologi koloni berwarna putih hingga krem, berbentuk bulat, elevasi cembung, dan struktur permukaan yang halus. Berdasarkan karakterisasi BAL, dari 28 isolat bakteri hanya diperoleh 5 isolat bakteri. Kelima isolat bakteri yang diduga memiliki karakter sebagai $\mathrm{BAL}$ yaitu NHC6, NHC7, NHC8, NHC9, dan NPC1. Kelima isolat tersebut membentuk zona bening pada saat ditumbuhkan pada media $\mathrm{CaCO}_{3} 0,3 \%(\mathrm{~b} / \mathrm{v})$, tidak memiliki katalase, dan tergolong bakteri Gram positif.

\section{Toleransi BAL terhadap kondisi asam}

Toleransi terhadap kondisi asam merupakan karakteristik penting yang harus dimiliki BAL sebagai probiotik. Ketahanan BAL asal jus nanas terhadap pH 2 menunjukkan toleransi yang berbeda-beda (Tabel 1). NHC6 mengalami peningkatan jumlah sel sebesar $0,4 \log \mathrm{CFU} / \mathrm{mL}$, sedangkan penurunan jumlah sel diperoleh keempat isolat lainnya yang mencapai 1,78 log CFU/mL. Kemampuan BAL asal jus nanas terhadap kondisi asam juga telah diuji oleh Phong et al. (2017) pada pH 2,5 dengan peningkatan jumlah sel BAL yang mencapai 5,4 log $\mathrm{CFU} / \mathrm{mL}$ setelah 2 jam inkubasi. Sebaliknya, penurunan jumlah sel isolat $\mathrm{NHC7}, \mathrm{NHC}$, $\mathrm{NHC}$, dan 
NPC1 (Tabel 1) sesuai dengan hasil yang diperoleh Garcia et al. (2016) pada kelima isolat Lactobacillus hasil isolasi pulp buah tropis yang hanya dapat mempertahankan viabilitas sel $<2 \log \mathrm{CFU} / \mathrm{mL}$ pada $\mathrm{pH} 2$ selama 2 jam inkubasi.

Tabel 1. Densitas BAL pada pH 2 setelah 2 jam waktu inkubasi

\begin{tabular}{lcc}
\hline \multirow{2}{*}{ Isolat BAL } & \multicolumn{2}{c}{ Densitas BAL (log CFU/mL) } \\
\cline { 2 - 3 } & $\begin{array}{c}\text { Jam ke-0 Inkubasi } \\
\left(\mathrm{T}_{0}\right)\end{array}$ & $\begin{array}{c}\text { Jam ke-2 Inkubasi } \\
\left(\mathrm{T}_{2}\right)\end{array}$ \\
\hline NHC 6 & $6,31 \pm 0,03$ & $6,76 \pm 0,64$ \\
NHC 7 & $6,65 \pm 0,10$ & $4,88 \pm 0,11$ \\
NHC 8 & $5,34 \pm 0,14$ & $5,04 \pm 0,06$ \\
NHC 9 & $6,09 \pm 0,28$ & $5,02 \pm 0,30$ \\
NPC 1 & $6,20 \pm 0,57$ & $5,25 \pm 0,19$ \\
\hline
\end{tabular}

Peningkatan jumlah sel dapat dikaitkan dengan kemampuan sel bakteri dalam meregulasi homeostatis pH intraseluler (Panjaitan et al., 2018). Sebaliknya, penurunan jumlah sel terjadi akibat reaksi oksidasi $\mathrm{HCl}$ terhadap sel bakteri, sehingga menyebabkan asidifikasi sitoplasma, kerusakan alat transport pada membran, dan penurunan aktivitas enzim seluler (Hamida et al., 2015).

\section{Toleransi BAL terhadap garam empedu}

Toleransi terhadap garam empedu merupakan salah satu kriteria seleksi untuk isolat bakteri probiotik agar dapat bertahan hidup pada usus kecil (Panjaitan et al., 2018). Semua isolat BAL kandidat probiotik asal jus nanas memiliki ketahanan terhadap $0,5 \%$ garam empedu (b/v) yang ditunjukkan dengan peningkatan jumlah sel (Tabel 2).

Peningkatan jumlah sel berkisar 0,42 log CFU/ $\mathrm{mL}$ hingga 1,4 log CFU/mL selama 5 jam inkubasi. Kelima isolat ini lebih baik dibandingkan dengan penelitian Hamida et al. (2015) yang melaporkan Pediococcus pentosaceus E5, E7, dan E8 asal fermentasi jagung mengalami penurunan viabilitas sel mencapai $0,64 \log \mathrm{CFU} / \mathrm{mL}$ pada kondisi $0,5 \%$ garam empedu setelah 2 jam inkubasi. BAL menghasilkan enzim bile salt hydrolase (BHS) yang dapat mendetoksifikasi asam empedu yang terkonjugasi menjadi dekonjugasi, sehingga tidak bersifat toksik bagi sel bakteri (Begley et al., 2006).

Tabel 2. Densitas BAL setelah 5 jam waktu inkubasi pada media $0,5 \%$ garam empedu

\begin{tabular}{lcc}
\hline \multirow{2}{*}{ Isolat BAL } & \multicolumn{2}{c}{ Densitas BAL $(\log \mathrm{CFU} / \mathrm{mL})$} \\
\cline { 2 - 3 } & $\begin{array}{c}\text { Jam ke-0 inkubasi } \\
\left(\mathrm{T}_{0}\right)\end{array}$ & $\begin{array}{c}\text { Jam ke-5 } \\
\text { Inkubasi }\left(\mathrm{T}_{5}\right)\end{array}$ \\
\hline NHC 6 & $7,42 \pm 0,09$ & $7,85 \pm 0,02$ \\
NHC 7 & $6,76 \pm 0,04$ & $7,84 \pm 0,04$ \\
NHC 8 & $6,36 \pm 0,30$ & $7,76 \pm 0,22$ \\
NHC 9 & $6,89 \pm 0,25$ & $7,86 \pm 0,26$ \\
NPC 1 & $6,79 \pm 0,17$ & $8,00 \pm 0,05$ \\
\hline
\end{tabular}

\section{Aktivitas antimikroba}

Empat dari lima CFS tanpa perlakuan dan $\mathrm{pH}$ 6,5 memiliki aktivitas antimikroba yang beragam terhadap tiga bakteri patogen uji (Tabel 3). CFS NPC1 pada semua perlakuan tidak menunjukkan aktivitas antimikroba terhadap ketiga patogen uji. Aktivitas antimikroba supernatan bebas sel tanpa perlakuan dan $\mathrm{pH}$ 6,5 ditunjukkan dari zona bening yang terbentuk dengan diameter 8,7-10,7 mm dan 8,2-9,9 $\mathrm{mm}$ (Tabel 3). Keempat isolat BAL asal jus nanas (NHC6, NHC7, NHC8, dan NHC9) memiliki aktivitas antimikroba yang lebih baik dibandingkan isolat genus Lactobacillus dari pulp buah tropis yang memiliki diameter zona bening $\geq 4 \mathrm{~mm}$ (Garcia et al., 2016). Aktivitas antimikroba yang dihasilkan pada supernatan bebas sel tanpa perlakuan dapat berasal dari asam organik yang dihasilkan oleh BAL sebagai hasil metabolismenya, seperti asam laktat yang bersifat bakterisidal terhadap bakteri Gram positif dan negatif (Panjaitan et al., 2018). Aktivitas antimikroba pada perlakuan supernatan bebas sel yang dinetralkan $(\mathrm{pH} \mathrm{6,5)} \mathrm{dapat} \mathrm{berasal} \mathrm{senyawa} \mathrm{organik}$ yang dihasilkan BAL seperti bakteriosin, diasetil, asam format, dan enzim yang bersifat bakteriolitik (Garcia et al., 2016).

Tabel 3. Aktivitas antimikroba pada supernatan bebas sel tanpa perlakuan dan $\mathrm{pH} 6,5$ terhadap bakteri patogen uji

\begin{tabular}{lcccccc}
\hline \multirow{2}{*}{$\begin{array}{c}\text { Supernatan } \\
\text { BAL }\end{array}$} & \multicolumn{5}{c}{ Tanpa Perlakuan } \\
\cline { 2 - 7 } & \multicolumn{7}{c}{ S. typhimurium } & S.aureus & E. coli & S. typhimurium & S.aureus & E. coli \\
\hline NHC6 & $10,6 \pm 0,18$ & $8,7 \pm 0,62$ & $9,4 \pm 0,53$ & $8,8 \pm 0,45$ & $9,5 \pm 0,71$ & $9,6 \pm 0,18$ \\
NHC7 & $10,3 \pm 0,35$ & $9,3 \pm 0,27$ & $9,4 \pm 1,15$ & $9,9 \pm 0,09$ & $9,5 \pm 0,71$ & $9,1 \pm 0,18$ \\
NHC8 & $10,7 \pm 0,26$ & $10,3 \pm 0,35$ & $9,3 \pm 0,35$ & $8,5 \pm 0,00$ & $8,2 \pm 0,21$ & $8,6 \pm 0,18$ \\
NHC9 & $10,4 \pm 0,18$ & $9,5 \pm 0,35$ & $9,8 \pm 1,68$ & $9,6 \pm 0,53$ & $9,3 \pm 0,35$ & $9,5 \pm 0,71$ \\
NPC1 & - & - & - & - & - & - \\
\hline
\end{tabular}


Hasil pembentukan zona bening pada supernatan bebas sel pH 6,5 yang dipekatkan terhadap ketiga bakteri patogen menunjukkan NHC6 memiliki hasil yang paling baik. NHC6 mampu menghambat S. aureus, S. typhimurium, dan E. coli pada konsentrasi $75 \mu \mathrm{l}$ dan $100 \mu \mathrm{l}$ (Tabel 4). NHC7, NHC8, dan NHC9 tidak menghasilkan zona bening pada $S$. aureus sesuai dengan hasil yang diperoleh Garcia et al. (2016) pada L. plantarum 111 dan L. brevis 59 yang tidak dapat menghambat $S$. aureus. Garcia et al. (2016) mengelompokkan peringkat sensitifitas terhadap patogen bawaan makanan adalah $S$. Typhimurium $>$ E. coli $>S$. aureus, sesuai dengan hasil yang diperoleh pada perlakuan supernatan bebas sel $\mathrm{pH} 6,5$ yang dipekatkan.

Tabel 4. Aktivitas antimikroba pada supernatan bebas sel $\mathrm{pH} 6,5$ hasil pemekatan terhadap bakteri patogen uji

\begin{tabular}{lcccc}
\hline Supernatan BAL & \multicolumn{4}{c}{ Diameter Zona $(\mathrm{mm})$} \\
\cline { 2 - 5 }$\quad$ dan Patogen & $25 \mu \mathrm{l}$ & $50 \mu \mathrm{l}$ & $75 \mu \mathrm{l}$ & $100 \mu \mathrm{l}$ \\
\hline NHC6+S. & - & $0,04 \pm$ & $0,13 \pm$ & $0,24 \pm$ \\
typhimurium & & 0,02 & 0,04 & 0,01 \\
NHC6+S. aureus & - & - & $0,21 \pm$ & $0,20 \pm$ \\
& & & 0,02 & 0,07 \\
NHC6+E. coli & - & - & $0,21 \pm$ & $0,25 \pm$ \\
& & & 0,02 & 0,07 \\
NHC7+S. & - & $0,04 \pm$ & $0,16 \pm$ & $0,14 \pm$ \\
typhimurium & & 0,01 & 0,02 & 0,02 \\
NHC7+S. aureus & - & - & - & - \\
NHC7+E. coli & - & $0,06 \pm$ & $0,21 \pm$ & $0,18 \pm$ \\
NHC8+S. & - & 0,02 & 0,02 & 0,04 \\
typhimurium & & - & $0,05 \pm$ & $0,14 \pm$ \\
NHC8+S. aureus & - & - & 0,04 & 0,02 \\
NHC8+E. coli & - & - & $0,05 \pm$ & - \\
NHC9+S. & - & - & $0,09 \pm$ & 0,02 \\
typhimurium & & & - & $0,04 \pm$ \\
NHC9+S. aureus & - & - & - & 0,02 \\
NHC9+E. coli & - & - & $0,01 \pm$ & - \\
NPC1+S. & - & - & $0,04 \pm$ & 0,02 \\
typhimurium & & & - & - \\
NPC1+S. aureus & - & - & - & - \\
NPC1+E. coli & - & - & - & - \\
\hline
\end{tabular}

\section{Kepekaan terhadap antibiotik}

Isolat $\mathrm{NHC6}, \mathrm{NHC7}, \mathrm{NHC}$, dan $\mathrm{NHC9}$ sensitif terhadap ampisilin, sedangkan NPC1 menunjukkan sifat resisten. Garcia et al. (2016) melaporkan 4 dari 5 isolat Lactobacillus asal fermentasi pulp buah sensitif terhadap ampisilin. Berdasarkan pengkategorian sifat kepekaan terhadap antibiotik oleh Haque et al. (2014), NHC6, NHC7, NHC9, dan NPC1 menunjukkan sifat resisten, sedangkan NHC8 menunjukkan sifat intermediet terhadap kloramfenikol. BAL resisten terhadap kloramfenikol terkait dengan adanya pengkode gen resisten cat (Haque et al., 2014). BAL dengan sifat resisten terhadap antibiotik dapat digunakan sebagai probiotik karena bersifat interinsik dan tidak dapat ditransferkan ke mikroflora usus (Garcia et al., 2016).

\section{Autoagregasi dan koagregasi}

Sifat agregasi bakteri merupakan salah satu karakteristik utama bakteri probiotik. Autoagregasi merupakan kemampuan bakteri beragregat terhadap sesamanya, sedangkan koagregasi adalah kemampuan bakteri dalam membentuk agregat dengan bakteri lain seperti bakteri patogen (Panjaitan et al., 2018). Empat dari lima isolat BAL menunjukkan nilai autoagregasi diatas $40 \%$ setelah diinkubasi selama 5 jam (Gambar 1). NHC6 memiliki kemampuan autoagregasi tertinggi sebesar $94,73 \%$. Nilai autoagregasi NHC6 lebih baik dibandingkan Enterococcus durans $\mathrm{K} 08$ hasil isolasi buah pisang yang hanya memiliki nilai autoagregasi $76,5 \%$ setelah 5 jam inkubasi (Divisekera et al., 2019).

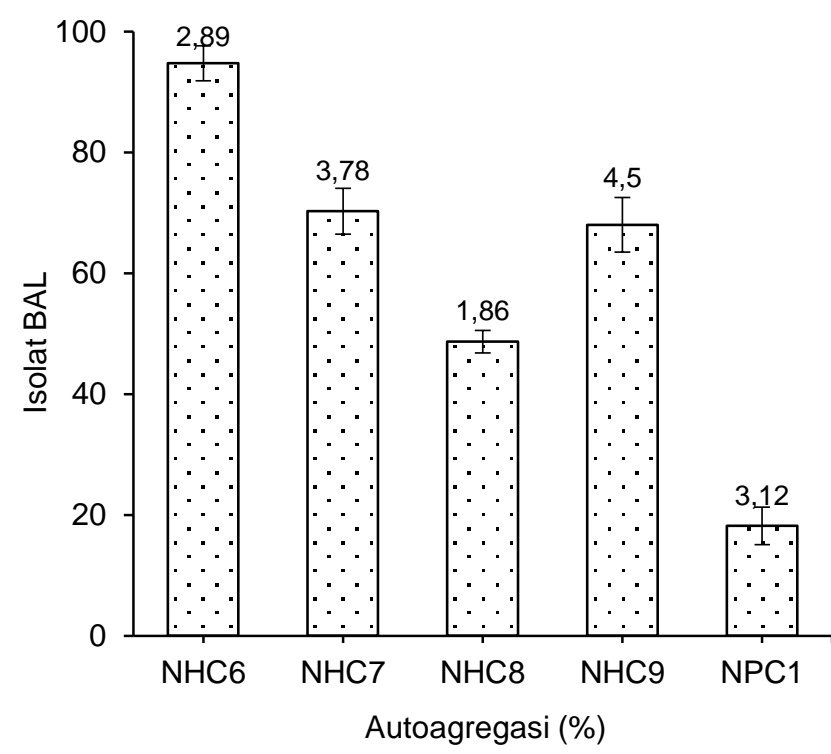

Keterangan: Hasil direpresentasikan sebagai nilai ratarata \pm SD pengulangan. Error bar mewakili standar deviasi

Gambar 1. Kemampuan autoagregasi (\%) BAL asal jus nanas pada 5 jam inkubasi

Kemampuan koagregasi terkuat setelah 5 jam inkubasi ditemukan pada NHC6 terhadap $S$. typhimurium yaitu sebesar 35,63\% (Tabel 5). Nilai koagregasi dapat dikategorikan sebagai koagregasi kuat jika memiliki nilai $>30 \%$. Nilai koagregasi yang diperoleh ini lebih baik dibandingkan $L$. fermentum S21209 terhadap S. typhimurium dengan nilai 
32,72\% setelah 5 jam inkubasi (Panjaitan et al., 2018).

Tabel 5. Kemampuan koagregasi (\%) BAL asal jus nanas terhadap tiga patogen uji

\begin{tabular}{cccc}
\hline $\begin{array}{c}\text { Isolat } \\
\text { BAL }\end{array}$ & S. typhimurium & S. aureus & E. coli \\
\hline NHC6 & $35,6 \pm 0,19$ & $7,2 \pm 0,04$ & $10,9 \pm 0,01$ \\
NHC7 & $29,8 \pm 0,27$ & $15,8 \pm 0,15$ & $16,6 \pm 0,18$ \\
NHC8 & $24,9 \pm 0,16$ & $0,1 \pm 0,02$ & $21,6 \pm 0,12$ \\
NHC9 & $31,6 \pm 0,06$ & $7,1 \pm 0,11$ & $27,8 \pm 0,13$ \\
NPC1 & $11,7 \pm 0,06$ & $3,9 \pm 0,05$ & $7,7 \pm 0,08$ \\
\hline
\end{tabular}

\section{Hidrofobisitas}

Metode MATS digunakan untuk mengevaluasi sifat permukaan sel hidrofobik bakteri untuk penempelan. Hasil pengujian ini menunjukkan NHC8 dan NHC9 memiliki sifat hidrofobik (30,34 dan $23,45 \%$ ) (Gambar 2) dengan afinitas sedang (20$30 \%)$ terhadap xilena berdasarkan katagori hidrofobik oleh Panjaitan et al. (2018). NHC8 dan NHC9 menunjukkan afinitas yang kuat terhadap etil asetat (31,74 dan 28,21\%), sehingga permukaan sel NHC8 dan NHC9 bersifat sebagai pendonor elektron. Etil asetat merupakan pelarut yang bersifat basa dan menunjukkan permukaan sel bakteri sebagai penerima elektron (Panjaitan et al., 2018). Hasil ini serupa dengan penelitian Xu et al. (2018) yaitu L. mesenteroides $\mathrm{B}-25$ memiliki sifat hidrofobik dengan afinitas kuat terhadap etil asetat (36,4\%). NHC6, NHC7, dan NPC1 memiliki sifat hidrofilik karena menunjukkan afinitas yang kuat terhadap etil asetat (Gambar 2).

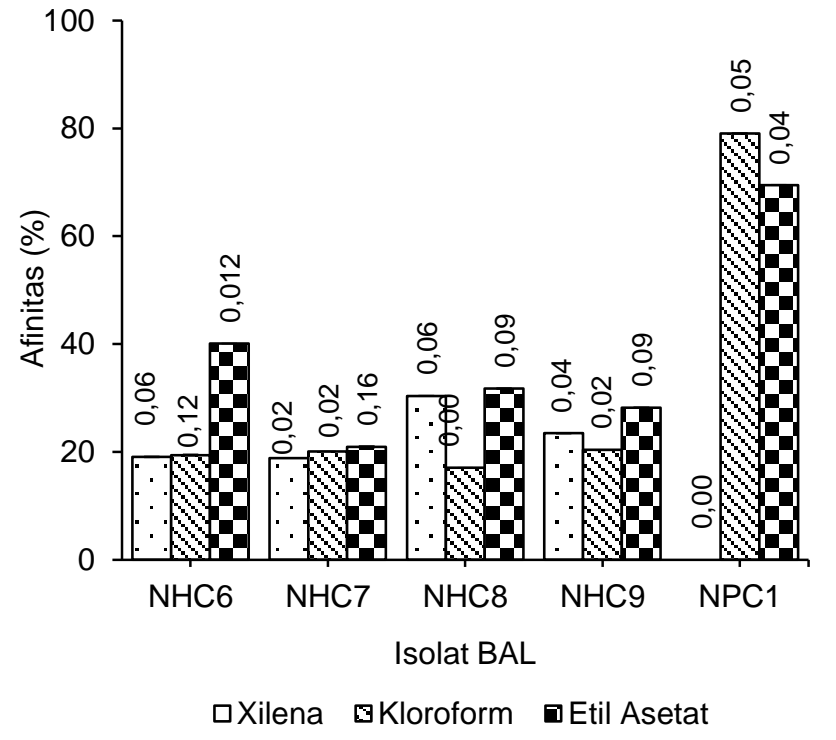

Keterangan: Hasil direpresentasikan sebagai nilai ratarata \pm SD pengulangan. Error bar mewakili standar deviasi

Gambar 2. Afinitas isolat BAL terhadap ketiga hidrokarbon uji

\section{Hasil identifikasi molekular BAL asal jus nanas}

Berdasarkan pengujian sifat probiotik, hanya NHC6, NHC7, NHC8, dan NHC9 yang memenuhi kriteria sebagai probiotik dan memiliki kekerabatan dengan L. plantarum, L. pentosus, dan L. Paraplantarum (Gambar 3).

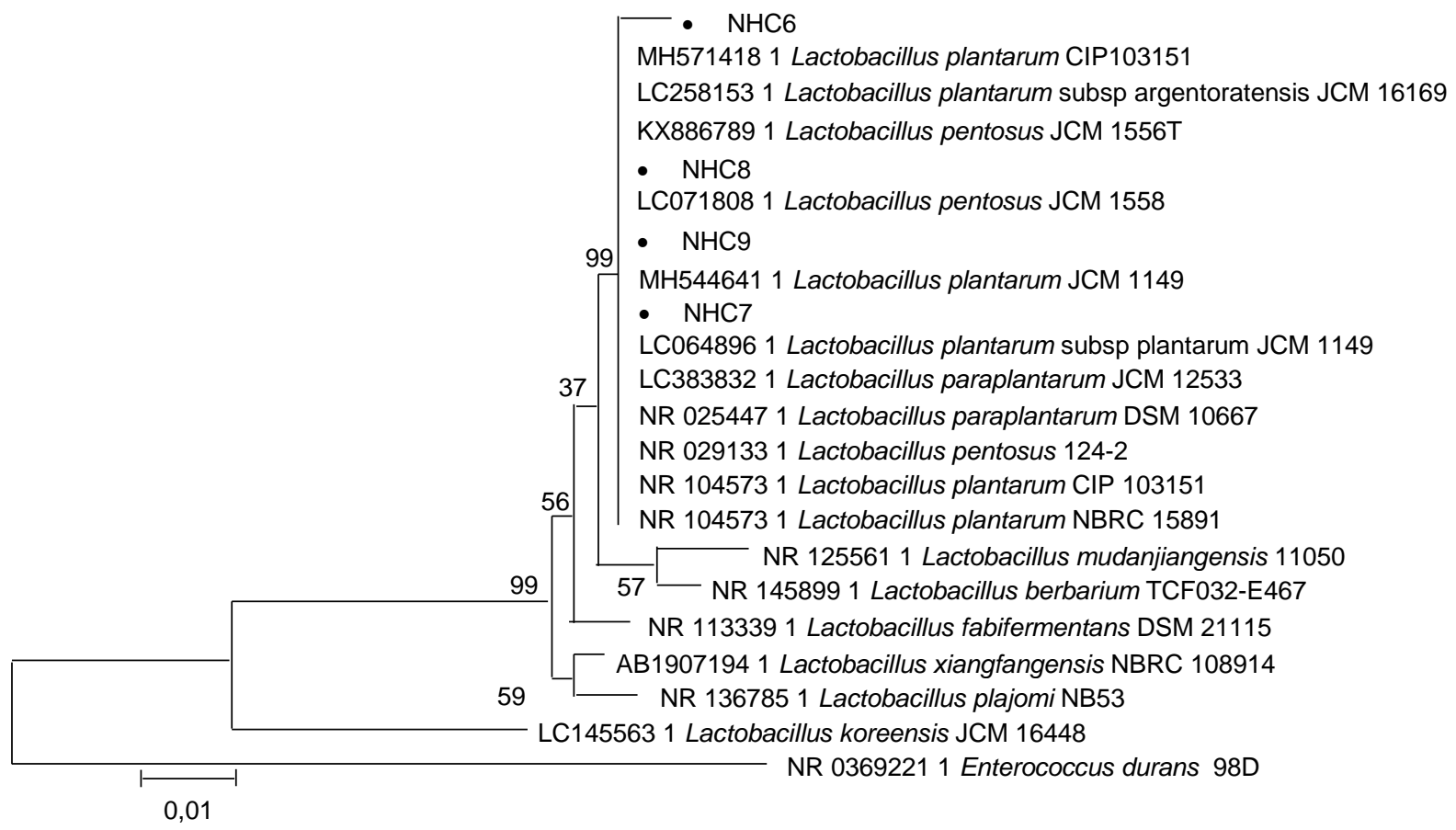

Gambar 3. Pohon filogenetik isolat BAL dengan metode Neighbor Joining (NJ) bootstrap 1000x 
Ketiga spesies bakteri tersebut masih termasuk ke dalam kelompok $L$. plantarum karena menunjukkan kemiripan fenotip yang tinggi (Pisano et al., 2010). L. plantarum merupakan kelompok bakteri Gram positif yang banyak ditemui pada buah (Kachouri et al., 2015). Keempat isolat asal jus nanas memiliki kekerabatan dekat dengan L. plantarum, sehingga isolat dengan karakter probiotik yang paling baik yaitu NHC6 dilanjutkan untuk pengujian selanjutnya.

\section{Hasil fermentasi jus nanas dan kapasitas anti- oksidan}

Inkubasi jus nanas dengan L. plantarum NHC6 dilakukan dengan melihat nilai ${ }^{\circ} \mathrm{Brix}, \mathrm{pH}$, densitas BAL, densitas khamir, dan aktivitas antioksidannya untuk dapat mengetahui kemampuan hidup terbaik, hasil tersebut tersaji pada Tabel 6 . Inkubasi $L$. plantarum NHC6 pada jus nanas selama 72 jam menunjukkan penurunan nilai ${ }^{\circ} \mathrm{Brix}$ dan $\mathrm{pH}$. Terjadinya penurunan disebabkan karena penggunaan gula menjadi asam laktat oleh $L$. plantarum NHC6. Penurunan ${ }^{\circ}$ Brix mencapai $0,9 \%(b / v)$ dengan $\mathrm{pH} 2,95$ selama 72 jam inkubasi dengan densitas $L$. plantarum NHC6 mencapai 9,27 log CFU/mL. Hasil ini lebih baik dibandingkan dengan penambahan konsorsium L. casei PTCC1608 dan L. acidophilus DSM pada fermentasi campuran jus barberry dan blackcherry yang hanya mencapai 8 log CFU/mL pada 72 jam inkubasi (Shisheh et al., 2014).

Penambahan L. plantarum NHC6 pada jus nanas selama 72 jam inkubasi menunjukkan penurunan aktivitas antioksidan (Tabel 6). Aktivitas antioksidan yang diperoleh menurun dari 90,64\% (jam ke-0 inkubasi) menjadi 81,28\% (jam ke-72 inkubasi) (Gambar 4). Hasil serupa juga diperoleh Li et al. (2018), fermentasi jus apel dengan L. plantarum FAJ mengalami penurunan aktivitas antioksidan bahkan mencapai $43,95 \%$ pada jam ke-72. Penurunan aktivitas antioksidan dapat terjadi karena kandungan antioksidan yang terdapat pada jus nanas dapat teroksidasi selama inkubasi (Ferreira et al., 2016). Terjadinya kenaikan dan penurunan aktivitas anti- oksidan juga tergantung pada jenis bakteri probiotik yang digunakan selama fermentasi (Budiari et al., 2019).

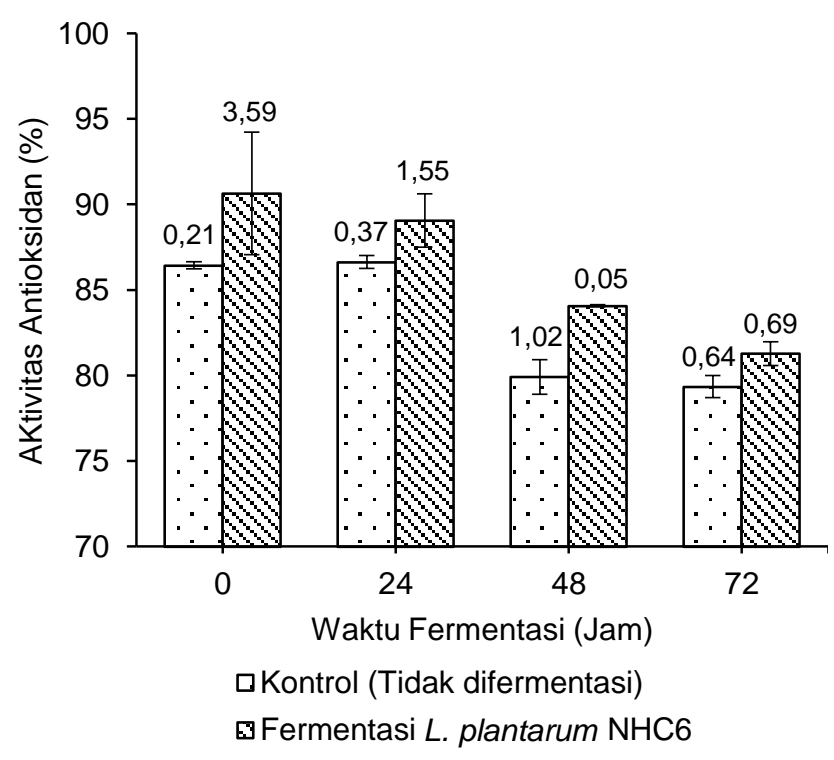

Gambar 4. Aktivitas antioksidan (\%) jus nanas selama waktu inkubasi

Penambahan L. plantarum NHC6 pada jus nanas tidak menunjukkan pertambahan aktivitas antioksidan, sehingga aktivitas antioksidan yang diperoleh merupakan antioksidan alami yang berasal dari nanas. Nanas mengandung antioksidan seperti fenol, karotenoid, dan vitamin C, akan tetapi kandungan antioksidan ini dapat teroksidasi selama proses fermentasi (Ferreira et al., 2016).

Densitas khamir terlihat pada jam ke-72 inkubasi mencapai 2,93 log CFU/mL. Pertumbuhan khamir ini dapat berasal dari jus nanas yang berperan dalam pembusukan buah. Keberadaan khamir pada buah dapat berasal dari kontaminan pasca panen (selama penyimpanan, pemindahan, dan pemrosesan). Beberapa spesies khamir yang sering ditemukan pada buah nanas adalah Debaryomyces polymorphus, C. pulcherrima, dan Pichia spp.

Tabel 6. Nilai ${ }^{\circ}$ Brix, $\mathrm{pH}$, densitas BAL, dan densitas khamir jus nanas selama waktu inkubasi

\begin{tabular}{|c|c|c|c|c|c|c|c|c|}
\hline \multirow{2}{*}{$\begin{array}{l}\text { Waktu } \\
\text { Inkubasi } \\
\text { (Jam) }\end{array}$} & \multicolumn{2}{|c|}{${ }^{\circ}$ Brix (\%) } & \multicolumn{2}{|c|}{$\mathrm{pH}$} & \multicolumn{2}{|c|}{$\begin{array}{c}\text { Densitas BAL (log } \\
\text { CFU } / \mathrm{mL})\end{array}$} & \multicolumn{2}{|c|}{$\begin{array}{c}\text { Densitas Khamir (log } \\
\text { CFU/mL) }\end{array}$} \\
\hline & $\begin{array}{c}L . \\
\text { plantarum } \\
\text { NHC6 }\end{array}$ & Kontrol & $\begin{array}{c}L . \\
\text { plantarum } \\
\text { NHC6 }\end{array}$ & Kontrol & $\begin{array}{c}L . \\
\text { plantarum } \\
\text { NHC6 }\end{array}$ & Kontrol & $\begin{array}{c}L . \\
\text { plantarum } \\
\text { NHC6 }\end{array}$ & Kontrol \\
\hline 0 & $13,8 \pm 0,00$ & $14,0 \pm 0,00$ & $3,5 \pm 0,00$ & $3,5 \pm 0,00$ & $6,41 \pm 0,01$ & $<1$ & $<1$ & $<1$ \\
\hline 24 & $13,5 \pm 0,14$ & $13,9 \pm 0,00$ & $3,25 \pm 0,07$ & $3,5 \pm 0,00$ & $8,33 \pm 0,19$ & $<1$ & $<1$ & $<$ \\
\hline 48 & $13,3 \pm 0,14$ & $13,85 \pm 0,07$ & $3,05 \pm 0,07$ & $3,5 \pm 0,00$ & $8,81 \pm 0,61$ & $<1$ & $<1$ & $<1$ \\
\hline 72 & $12,9 \pm 0,14$ & $13,3 \pm 0,14$ & $2,95 \pm 0,07$ & $3,35 \pm 0,07$ & $9,27 \pm 0,32$ & $<1$ & $2,92 \pm 0,35$ & $3,64 \pm 0,63$ \\
\hline
\end{tabular}


Berdasarkan Tabel 6, tidak adanya pertumbuhan khamir pada waktu inkubasi 24 jam serta densitas BAL telah mencapai 8,33 log CFU/mL. Densitas BAL yang diperoleh sesuai dengan jumlah bakteri yang diperlukan pada produk minuman fermentasi yaitu minimal 7 log CFU/mL (Perricone et al., 2015). Selain itu, aktivitas antioksidan hanya mengalami sedikit penurunan $(89,05 \%)$ dibandingkan pada jam ke-72 inkubasi $(81,28 \%)$ (Gambar 4$)$. Berdasarkan data tersebut, jam ke-24 inkubasi dipertimbangkan sebagai waktu inkubasi paling baik pada jus nanas dibandingkan dengan waktu inkubasi lainnya.

\section{KESIMPULAN}

NHC6 merupakan BAL asal jus nanas yang berpotensi sebagai bakteri probiotik. NHC6 memiliki kekerabatan dekat dengan Lactobacillus plantarum. Aktivitas antioksidannya mencapai 89,05\% dengan densitas BAL mencapai $8,33 \log \mathrm{CFU} / \mathrm{mL}$ pada waktu inkubasi 24 jam. Oleh karena itu, L. plantarum NHC6 merupakan isolat BAL asal jus nanas yang paling potensial yang dapat diaplikasikan pada produk makanan probiotik.

\section{UCAPAN TERIMA KASIH}

Penelitian ini didukung oleh dana hibah penelitian tesis dari Kementerian Riset, Teknologi dan Pendidikan Tinggi (4395/IT3.L1/PN/2019) atas nama Anja Meryandini.

\section{DAFTAR PUSTAKA}

Begley M, Hill C, Gahan CGM. 2006. Bile salt hydrolase activity in probiotics. Appl Environ Microbiol 72: 1729-1738. DOI: 10.1128/AEM.72.3.17 29-1738.2006.

Budiari S, Maryati Y, Susilowati A, Mulyani H, Lotulung PDN. 2019. The effect of lactic acid fermentation in antioxidant activity and total polyphenol contents of the banana (Musa acuminate Linn) juice. AIP Conf Proc 2175. DOI: 10.1063/1.5134588.

Divisekera DMWD, Samarasekera JKRR, Hettiarachchi C, Gooneratne J, Choudhary MI, Gopalakrishnan S. 2019. Isolation and identification of lactic acid bacteria with probiotic potential from fermented flour of selected banana va- rieties grown in Sri Lanka. J Natl Sci Found Sri 47: 3-16. DOI: 10.4038/jnsfsr.v47i1.8922.

Ferreira EA, Siquera HE, Boas EVV, Hermes VS, Rios ADO. 2016. Bioactive compounds and antioxidant activity of pineapple fruit of different cultivars. Rev Bras Frutic 38: 1-7. DOI: 10.159 0/0100-29452016146.

Garcia EF, Luciano WA, Xavier DE, da Costa WC, Oliviera KD, Franco OL, Júnior MAD, Lucena BTL, Picão RC, Magnani $M$, Saarela $M$, de Souza EL. 2016. Identification of lactic acid bacteria in fruit pulp processing by products and potential probiotic properties of selected Lactobacillus strains. Front Microbiol 7: 1-11. DOI: 10.3389/fmicb.2016.01371.

Hamida F, Wiryawan KG, Meryandini A. 2015. Selection of lactic acid bacteria as probiotic candidate for chicken. Media Peternakan 38: 138144. DOI: 10.5398/medpet.2015.38.2.138.

Haque KMF, Yusof RM, Huq AKO, Khaleque HN. 2014. Antibiotic susceptibility of lactic acid bacteria and Bifidobacteria. J Microbiol and Virol 4: 7-14.

Kachouri F, Ksontini H, Kraiem M, Setti K, Machmeche M, Hamdi M. 2015. Involvement of antioxidant activity of Lactobacillus plantarum on functional properties of olive phenolic compounds. J Food Sci Technol 52: 7924-7933. DOI: 10.1007/s13197-015-1912-2.

Kos B, Šušković J, Vuković S, Šimpraga M, Frece J, Matošić S. 2003. Adhesion and aggregation ability of probiotic strain Lactobacillus acidophillus M92. J Appl Microbiol 94: 981-987. DOI: 10.1046/j.1365-2672.2003.01915.x.

Lee KW, Park JY, Sa HD, Jeong JH, Jin DE, Heo HJ, Kim JH. 2014. Probiotic properties of Pediococcus strains isolated from jeotgals, salted and fermented korean sea-food. Anaerobe 28: 199206. DOI: 10.1016/j.anaerobe.2014.06.013.

Li Z, Teng J, Lyu Y, Hu X, Zhao Y, Wang Z. 2018. Enhanced antioxidant activity for apple juice fermented with Lactobacillus plantarum ATCC14 917. Molecules 24: 1-12. DOI: 10.3390/molecu les24010051.

Marchesi JR, Sato T, Weightman AJ, Martin TA, Fry JC, Hiom SJ, Wade WG. 1998. Design and evaluation on useful bacterium-spesific PCR primers that amplify genes coding for bacterial 16S rRNA. Appl Environ Microbiol 64: 795-799. DOI: 10.1128/AEM.64.2.795-799.1998. 
Panjaitan R, Nuraida L, Hariyadi RD. 2018. Seleksi isolat bakteri asam laktat asal tempe dan tape sebagai kandidat probiotik. J Teknol Industri Pangan 29: 175-184. DOI: 10.6066/jtip.2018. 29.2.175.

Perricone $M$, Bevilacqua A, Altieri C, Sinigaglia M, Corbo MR. 2015. Challenge for the production of probiotic fruit juices. Beverages 1: 95-103. DOI: 10.3390/beverages 1020095 .

Phong HX, Quyen MT, Thanh NN, Long BHD, Dung NTP. 2017. Selection of high acid producing lactic acid bacteria and potential application in pineapple juice fermentation. Bioprocess Eng 1: 58-64.

Shisheh S, Hashemiravan M, Jaktaji RP. 2014. Production of probiotic mixture of barberry and black cherry juice by lactic acid bacteria. Bull Env Pharmacol Life Sci 3: 53-61.
Sornplang P, Piyadeatsoontorn S. 2016. Probiotic isolates from unconventional sources. J Anim Sci Technol 52: 6112-6124. DOI: 10.1186/s407 81-016-0108-2.

Pisano MB, Patrignani F, Cosentino S, Guerzoni ME, Franz CMAP, Holzapfel WH. 2010. Diversity and functional properties of Lactobacillus plantarum-group strains isolated from Italian cheese product. Dairy Sci Technol 91: 65-76. DOI: $10.1051 / \mathrm{dst} / 2010037$.

Xu X, Luo D, Bao Y, Liao X, Wu J. 2018. Characterization of diversity and probiotic efficiency of the autochthonous lactic acid bacteria in the fermentation of selected raw fruit and vegetable juices. Front Microbiol 9: 2539. DOI: 10.3389/f micb.2018.02539. 